\title{
Is Environmental Efficiency Compatible with Economic Competitiveness in Dairy Farming? A Case Study of 80 Luxembourgish Farms
}

\author{
Rocco Lioy, Caroline Battheu-Noirfalise, Aline Lehnen, Roman Reding, \\ and Tom Dusseldorf
}

\begin{abstract}
The aim of the study was to investigate both environmental and economic performances of Luxembourgish dairy farms in order to assess possibilities and limits of improving economic competitiveness via increasing environmental efficiency. In the environmental field, four LCA impact categories (carbon footprint, energy consumption, acidification, eutrophication) were analysed, while in the economic field, costs, incomes and profit of the farms were investigated. A main result was that a sustainable dairy production with less environmental impact in all considered categories is also of advantage in terms of farm competitiveness. The most efficient farms reach also the highest profit. The case study proves that a high environmental performance is not only of advantage in terms of economic competitiveness, but is even a necessary prerequisite for best economic performances.
\end{abstract}

\section{Introduction}

The case study was carried out in the frame of the Interreg VA Program of the European Union (Project AUTOPROT). This project aims to investigate if and to which extent an increase of protein self-sufficiency (autarky) can lead to a better competitiveness of dairy farms and to a reduction of their environmental impact as well. After the abolition of the milk quota system in the European Union at the end of March 2015, dairy farms were forced more than ever to increase production efficiency as a precondition to improve their own competitiveness. Thus, in the frame of this study, a combined environmental and economic analysis of dairy farms was

R. Lioy $(\square) \cdot$ A. Lehnen $\cdot$ R. Reding $\cdot$ T. Dusseldorf CONVIS Société Coopérative, Ettelbruck, Luxembourg

e-mail: rocco.lioy@convis.lu

C. Battheu-Noirfalise

Centre Wallon de Recherches Agronomiques (CRA-W), Libramont, Belgium

(C) The Author(s) 2022

Z. S. Klos et al. (eds.), Towards a Sustainable Future - Life Cycle Management, https://doi.org/10.1007/978-3-030-77127-0_5 
carried out in order to highlight possibilities and limitations of a conciliation of environment and competitiveness in dairy farming.

\section{Material and Methods}

\subsection{The Investigated Farms and the Protein Autarky}

The investigation refers to a sample of 80 Luxembourgish dairy farms supervised in the years 2014, 2015 and 2016. The figures of crop production and animal husbandry of the investigated farms (Tables 1 and 2) as well as all the figures presented in this study refer to the average of the three investigation years. The farms (ca. 11\% of all dairy farms of the land) cover the different dairy production systems in the country and are representative of dairy production in Luxembourg.

A very important indicator for the farms is the self-sufficiency degree of protein in dairy farms, in subsequently called protein autarky. There are two possibilities to express protein autarky. The first one refers to the performance of farm crop production to deliver protein for the herd. In case of crop production, the autarky is the amount of on-farm produced protein in relation to the total protein fed [1]. The other indicator of protein autarky refers to the performance of animal production to valorise protein fed. This figure takes into account the protein need based on need Tables [2] and considers as valorised the difference between needed and purchased (with concentrate and roughage) protein. The purchased protein is estimated based on feed protein Tables [3]. A detailed description of this figure is shown in [4].

\subsection{The LCA Methodology Applied and Economic Indicators Used}

The investigation of environmental impact was carried out on four LCA midterm impact categories (carbon footprint, energy consumption, acidification and eutrophication). The carbon footprint takes into account not only emissions deriving from production means, animal husbandry and crop production but also carbon credits deriving from humus storage into arable soils and via renewable energies

Table 1 Main figures of crop production

\begin{tabular}{l|r|l}
\hline Figure & Average & St. dev. \\
\hline Farm size (dairy production) & 87.08 ha & $45 \%$ \\
\hline Cereals & 8.25 ha & $78 \%$ \\
\hline Maize silage & 16.39 ha & $54 \%$ \\
\hline Grassland (permanent + temporary) & 61.89 ha & $46 \%$ \\
\hline Other feed plants & 0.55 ha & $328 \%$ \\
\hline
\end{tabular}


Table 2 Main figures of animal husbandry

\begin{tabular}{l|l|l}
\hline Figure & Average & St. dev. \\
\hline Animal density & $1.56 \mathrm{LAU} / \mathrm{ha}$ & $19 \%$ \\
\hline Dairy cows & $84 \mathrm{n})$ & $55 \%$ \\
\hline Production intensity & $7.550 \mathrm{~kg}$ ECM$/ \mathrm{ha}$ & $29 \%$ \\
\hline Dairy performance & $7.847 \mathrm{~kg} \mathrm{ECM} / \mathrm{year}$ & $15 \%$ \\
\hline Concentrate use & $6.33 \mathrm{~kg} / \mathrm{cow} /$ day & $26 \%$ \\
\hline Concentrate efficiency & $0.29 \mathrm{~kg} / \mathrm{kg} \mathrm{ECM}$ & $21 \%$ \\
\hline
\end{tabular}

LAU Large animal unit, ECM Energy-corrected milk

Table 3 Sources of emission and credit factors for carbon footprint

\begin{tabular}{l|l}
\hline Emission or credit post & Source \\
\hline Production means (manufacturing and transport) & Ecoinvent 2009 [5] \\
\hline Enteric fermentation and manure management & IPCC 2006 [6] \\
\hline Indirect soil emissions & IPCC 2006 [6] \\
\hline Mineral nitrogen fertilisation & IPCC 2006 [6] \\
\hline Fuel (manufacturing and combustion) & Ecoinvent 2009 [5] \\
\hline Humus balance of arable land & Leithold et al. 1997 [7] \\
\hline Electricity from biogas & Ecoinvent 2009 [5] \\
\hline
\end{tabular}

(Table 3). This means that the carbon footprint results in a net balance of CO2-equivalents.

In the case of humus balance of arable soils [7], the balance results in an emission if negative, and in a credit, if positive. The global warming factors used for carbon footprint were 25 for methane and 298 for dinitrogen oxide, according to [6]. The allocation between milk and meat was carried out following their protein content.

The energy consumption (no renewable energy) was estimated by taking into account not only direct energy (fuel and electricity) but also the indirect energy for manufacturing and transport of used production means and investments (buildings and machinery). The source of these energy consumptions was the Ecoinvent databasis [5].

Acidification takes into account the SO2-equivalents deriving from $\mathrm{SO} 2, \mathrm{NH} 3$ and NOx. The sources for the emission factors for the three gases were in the case of used production means [5] and in the case of livestock and crop production [8] for NH3 and [6] for NOx (as NO). The characterisation factors for NH3 and NOx (as NO) were derived from [9].

Finally, in the case of eutrophication, the estimation of nitrate leaching was made as difference between the nitrogen balance at farm gate and the sum of all emission of N-species as well as the N-storage into the soil, in analogy to [10]. The PO4equivalents coming from phosphorous emission are estimated based on farm gate balance for phosphorus. Even in the case of eutrophication, characterisation factors for PO4-equivalents from different eutrophication sources were derived from [9].

As shown by [11] and [12], the behaviour of carbon footprint when expressed in function of product ( $\mathrm{kg} \mathrm{ECM}$ ) or farm size (ha) is contradictory. Thus, to avoid 
misunderstandings in interpretation of results, for all investigated impact categories, both functional units (per kg ECM and per ha) were used.

In this study, the incomes without subsidies, the production costs for a $\mathrm{kg}$ ECM as well as the profit (as a difference between the first two) were used as economic indicators.

\subsection{The Principle of Farm Segregation and Statistics Analysis}

In order to analyse result variability, according to [13], the investigated farms have been divided into groups by crossing the $\mathrm{X}$ and the $\mathrm{Y}$ axis in the average value of carbon footprint per ha (11.2 t CO2eq) and per $\mathrm{kg}$ ECM (1.32 kg CO2eq) (see Fig. 1).

This allows the segregation of farms into four groups, which are well differentiated in terms of production intensity and efficiency of production mean use (as will be clear more below, Fig. 4). In particular, the farms with only one indicator of carbon footprint better than the average are farms with the highest or lowest production intensity. The farms of the other two groups (with both values of carbon footprint better or worse than the average) are farms with a middle-intensive production intensity, when compared with the other two groups. Figure 1 also shows the used denomination of the four farm groups.

Concerning the statistic methodology, the analysis was carried out by using the program "R", which is freely available on the Internet [14]. ANOVA test was used for determining the significance of selected figures in the whole pool, while Tukey post hoc test was used among the segregated farm groups. The conditions of

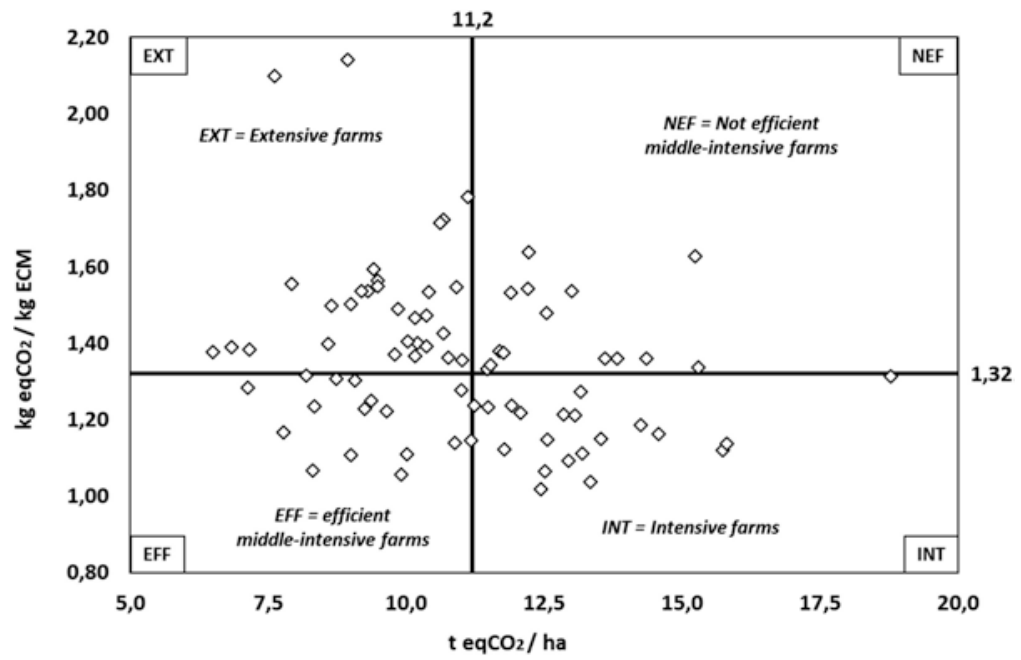

Fig. 1 The segregation and the denomination of the four farm groups 
application of the ANOVA test, homogeneity and homoscedasticity, were tested using the Shapiro test and the Bartlett test, respectively. An exhaustive description of ANOVA test can be found under [15].

\section{Results and Discussion}

The value of protein autarky of crop production of investigated farms (Table 4) shows that two thirds of the protein fed were produced on farm, and the other third was purchased. In the case of animal production, on average the farms show a valorisation of the on-farm produced protein of $49 \%$.

This means that roughly one half of the on-farm produced protein is lost. These losses are problematic, because they result in higher emissions (especially NH3, [16]) and in a higher import of feed (with consequent higher energy consumption and carbon footprint). In terms of variability, the purchased protein shows the maximum value. As we will see below (Fig. 5), the protein purchase plays a key role in explaining differences among the farms.

The results of LCA impact categories show a very high variability both in product (Table 5)- and in surface (Table 6)-related figures. The largest spread between minima and maxima values can be found in the eutrophication figures. The calculated figures for dairy farming in Luxembourg are consistent with the range of values from literature [17-19] concerning all product-related figures as well as surface-related figures of carbon footprint and energy consumption. Only in the case of surface-related figures of acidification and eutrophication, it was not possible to find values in the literature because relating these figures to the farm area is unusual.

In the case of economic results (Table 7), there is an evident difference between incomes and costs on the one hand and profit on the other hand. Indeed, the variability of the first two parameters is clearly lower than those for the profit, which varies very largely among the farms. In any case, on an average, the farms are capable of reaching only a very low profit, if subsidies are not considered.

Table 4 Figures of protein autarky of investigated farms

\begin{tabular}{l|l|l}
\hline Protein autarky & Value & St. dev. \\
\hline On-farm produced protein $(1)$ & $966 \mathrm{~kg} \mathrm{CP} / \mathrm{ha}$ & $54 \%$ \\
\hline Purchased protein $(2)$ & $497 \mathrm{~kg} \mathrm{CP} / \mathrm{ha}$ & $81 \%$ \\
\hline Total protein fed $(3)=(1)+(2)$ & $1.462 \mathrm{~kg} \mathrm{CP} / \mathrm{ha}$ & $60 \%$ \\
\hline $\begin{array}{l}\text { On-farm protein autarky }=(1) / \\
(3) * 100\end{array}$ & $66 \%$ & $14 \%$ \\
\hline Needed protein by dairy herd (4) & $982 \mathrm{~kg} \mathrm{CP} / \mathrm{ha}$ & $62 \%$ \\
\hline Valorised protein $(5)=(4)-(2)$ & $485 \mathrm{~kg} \mathrm{CP} / \mathrm{ha}$ & $58 \%$ \\
\hline $\begin{array}{l}\text { CP-autarky (anim. prod.) })(5) / \\
(4) * 100\end{array}$ & $49 \%$ & $29 \%$ \\
\hline CP Crude protein & & \\
\hline
\end{tabular}


Table 5 Product-related impact of farms in the investigated LCA categories

\begin{tabular}{l|l|l|l|l}
\hline Impact category & $\begin{array}{l}\text { Functional unit: } \\
1 \mathrm{~kg} \text { ECM }\end{array}$ & St. dev. & Min. & Max. \\
\hline Carbon footprint & $1.32 \mathrm{~kg} \mathrm{CO} 2 \mathrm{eq}$ & $16 \%$ & 1.02 & 2.14 \\
\hline Energy consumption & $4.8 \mathrm{MJ}$ & $19 \%$ & 3.3 & 8.0 \\
\hline Acidification & $17.3 \mathrm{~g} \mathrm{SO} 2 \mathrm{eq}$ & $21 \%$ & 12.0 & 36.3 \\
\hline Eutrophication & $11.7 \mathrm{~g} \mathrm{PO} 4 \mathrm{eq}$ & $36 \%$ & 6.1 & 29.4 \\
\hline
\end{tabular}

Table 6 Surface-related impact of farms in the investigated LCA categories

\begin{tabular}{l|l|l|l|l}
\hline Impact category & $\begin{array}{l}\text { Functional unit: } \\
1 \text { ha }\end{array}$ & St. dev. & Min. & Max. \\
\hline Carbon footprint & 11.2 t CO2eq & $21 \%$ & 6.5 & 18.8 \\
\hline Energy consumption & 41 GJ & $27 \%$ & 19 & 65 \\
\hline Acidification & $148 \mathrm{~kg} \mathrm{SO} 2 \mathrm{eq}$ & $23 \%$ & 80 & 230 \\
\hline Eutrophication & $99 \mathrm{~kg}$ PO4eq & $33 \%$ & 35 & 196 \\
\hline
\end{tabular}

Table 7 Economic figures of investigated farms (incomes are without subsidies)

\begin{tabular}{l|l|l|l|l}
\hline Economic figures & $€$-cent/kg ECM & St. dev. & Min. & Max. \\
\hline Incomes & 39.7 & $9 \%$ & 34.3 & 55.7 \\
\hline Costs & 38.8 & $20 \%$ & 23.1 & 63.2 \\
\hline Profit (incomes-costs) & 0.9 & $822 \%$ & -24.6 & 19.9 \\
\hline
\end{tabular}

Table 8 LCA figures of segregated farm groups and range of results

\begin{tabular}{|c|c|c|c|c|c|c|c|c|}
\hline LCA figure & EFF & Range & EFF & Range & EFF & Range & EFF & Range \\
\hline $\mathrm{Kg} \mathrm{CO}_{2} \mathrm{eq} / \mathrm{kg} \mathrm{ECM}$ & 1.2 & 2 & 1.17 & 1 & 1.51 & 4 & 1.45 & 3 \\
\hline $\mathrm{t} \mathrm{CO}_{2} \mathrm{eq} / \mathrm{ha}$ & 9.2 & 1 & 13.9 & 4 & 9.5 & 2 & 12.6 & 3 \\
\hline $\mathrm{MJ} / \mathrm{kg} \mathrm{ECM}$ & 4.4 & 2 & 4.3 & 1 & 5.3 & 4 & 5.1 & 3 \\
\hline GJ/ha & 34 & 2 & 51 & 4 & 34 & 1 & 45 & 3 \\
\hline $\mathrm{g} \mathrm{SO}_{2} \mathrm{eq} / \mathrm{kg} \mathrm{ECM}$ & 16.6 & 2 & 15.4 & 1 & 19.5 & 4 & 18.9 & 3 \\
\hline $\mathrm{Kg} \mathrm{SO}_{2} \mathrm{eq} / \mathrm{ha}$ & 127 & 2 & 182 & 4 & 123 & 1 & 164 & 3 \\
\hline $\mathrm{g} \mathrm{PO}_{4} \mathrm{eq} / \mathrm{kg} \mathrm{ECM}$ & 10.5 & 2 & 9.7 & 1 & 14.1 & 4 & 13.3 & 3 \\
\hline $\mathrm{Kg} \mathrm{PO}_{4} \mathrm{eq} / \mathrm{ha}$ & 81 & 1 & 115 & 3 & 88 & 2 & 116 & 4 \\
\hline Sum of ranges & - & 14 & - & 19 & - & 22 & - & 25 \\
\hline
\end{tabular}

The farm segregation allows ranging the results among farm groups. As can be seen in Table 8, the middle-intensive farms with a high efficiency (EFF) show the lowest environmental impact, if all the ranges in the eight impact categories are added up. In the hierarchy of the range, the group EFF is followed by the intensive farms (INT), then by the extensive (EXT) and finally by the middle-intensive farms with a low efficiency (NEF). In the case of product-related emissions, the farm group INT each times reaches the best performances, but this situation inverts when the results are related to the ha of the farm. In that case, the intensive farm group shows the weakest results in the range with only one exception (kg PO4eq/ha). 


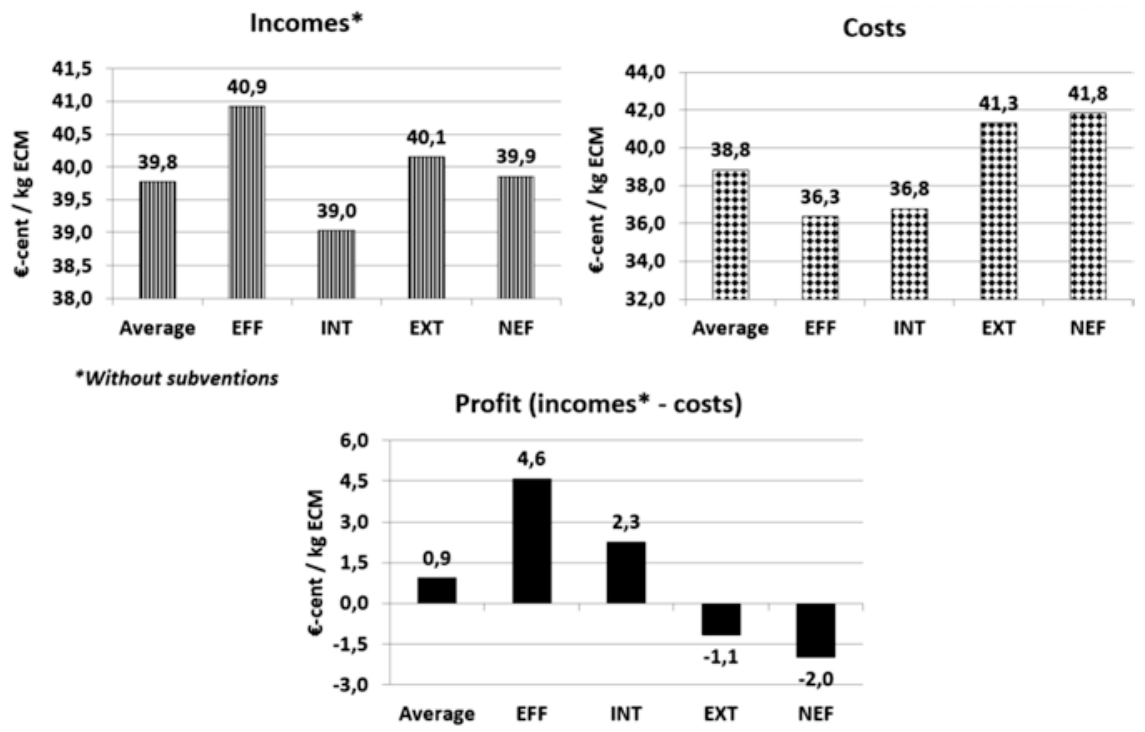

Fig. 2 Economic figures of segregated farm groups

The situation of the extensive farm group (EXT) is inverse to the intensive farms. This suggests that the farm structure is important in order to influence the range of result.

This hierarchy in environmental results among the farm groups is found to be the same also as in the case of economic results. As shown in Fig. 2, the farm group EFF reaches the best profit per kg ECM, followed by the groups INT, EXT and NEF.

It should also be noted that the farms of the group EFF have the highest value in terms of incomes and the lowest value in terms of costs, which explains the higher profit in comparison with the other groups. It is also interesting to observe that intensive farms are able to keep the costs low, but in terms of income, they reach the lowest rates. The other two groups (EXT and NEF) are not able to reach a positive profit, if subsidies are not taken into consideration.

In order to explain this hierarchy in the results, it is helpful to show the figures linked to the structure (Fig. 3) as well as to the management of the farm groups (Fig. 4). The figures of animal density as well as production intensity confirm that the groups INT and EXT have respectively the highest and the lowest production intensity and that the other two groups (EFF and NEF) are located in between, with NEF showing on average a higher intensity than EFF. The EFF group shows the lowest value in the farm area and the second lowest value in terms of number of dairy cows, very close to the lowest value of EXT group. This is a first hint that the farms of the EFF group try to capitalise maximally their own resources because these are limited in comparison with other groups. It appears consistent with the figures of animal density and production intensity that intensive farms (INT) show the highest values in farm size as well as in number of cows. 
Animal density (LAU/ha)
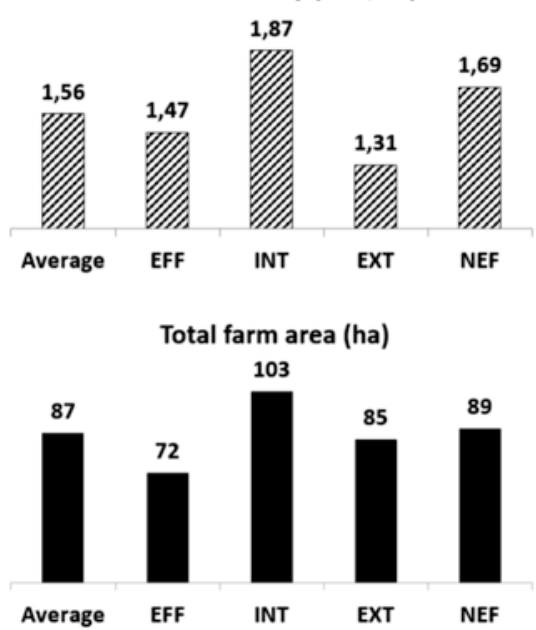

Production intensity (kg ECM/ha)

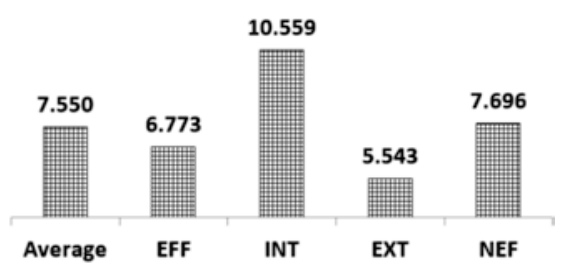

Dairy cows (number)

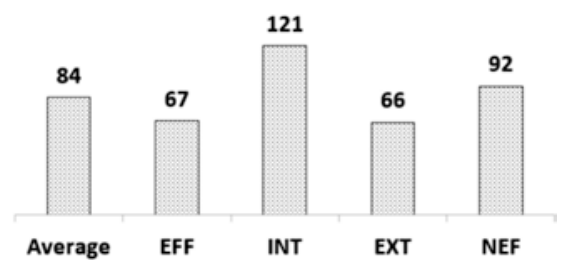

Fig. 3 Main figures of farm groups related to the farm structure

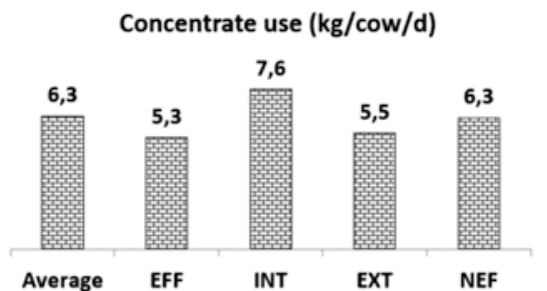

Protein autarky of crop production

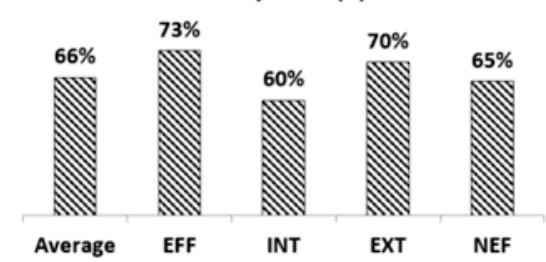

\section{Concentrate efficiency (kg/kg ECM)}

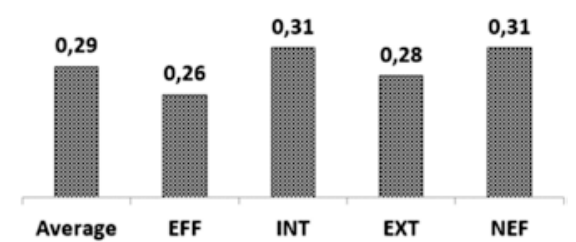

Protein autarky of animal production

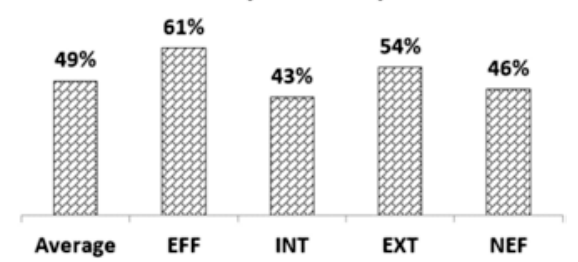

Fig. 4 Main figures of farm groups related to the feeding management

A second important point concerns the influence of management quality on the environmental impact of farm groups. As can be observed in Fig. 4, the most efficient farms (EFF) show also the best values not only in concentrate management but also in protein autarky. This is consistent with observation of other authors [20,21], who stressed that feed management has a huge impact on the environmental result in livestock/dairy production in general and on carbon footprint in particular. 

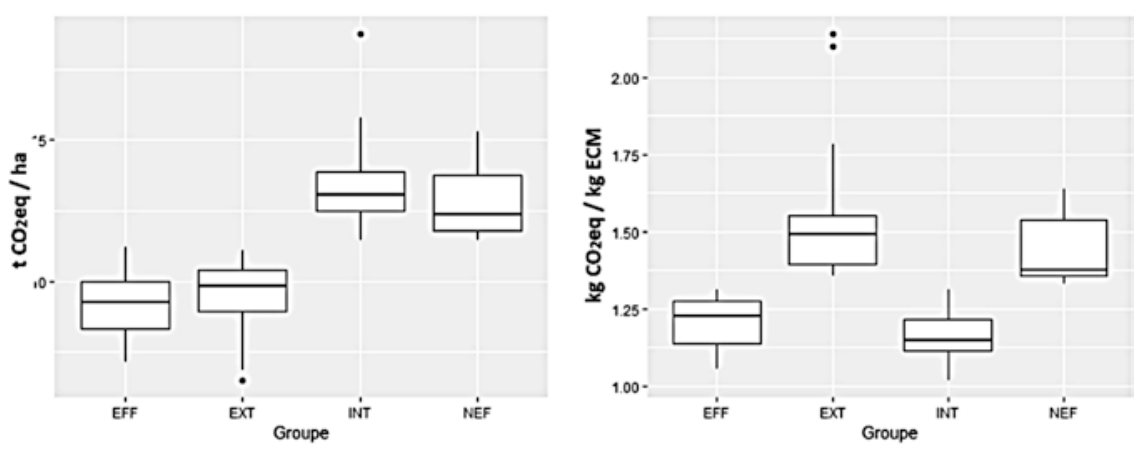

\begin{tabular}{|c|c|c|c|c|c|c|c|}
\hline Variable & $\begin{array}{c}\text { Significance } \\
\text { [ANOVA] }\end{array}$ & EXT-EFF & INT-EFF & NEF-EFF & INT-EXT & NEF-EXT & NEF-INT \\
\hline $\mathrm{t} \mathrm{CO}_{2}$ eq $/ \mathrm{ha}$ & 0,0000 & ns & 0,0000 & 0,0000 & 0,0000 & 0,0000 & ns \\
\hline $\mathrm{kg} \mathrm{CO}$ eq $/ \mathrm{kg} \mathrm{ECM}$ & 0,0000 & 0,0000 & ns & 0,0000 & 0,0000 & ns & 0,0000 \\
\hline
\end{tabular}

Fig. 5 Statistics of carbon footprint for the farm groups ( $n s$ not significant)

Further, it is interesting to point out that the hierarchy in feed management, as shown in Fig. 4, is more similar to the figures of surface-related impacts (Table 8) than to those of product-related ones. Indeed, if results are expressed per ha, extensive farms score better than intensive ones, and the latter show the worse result, which also is the case in Fig. 4. The highest level of milk production of intensive farms is evidently capable of concealing deficits in important management sectors such as feeding and providing better figures for these farms, if results are expressed related to the $\mathrm{kg}$ ECM.

A last consideration concerns statistical significance of differences in results among farm groups. As shown in Fig. 5 (for reasons of space, the analysis refers only to carbon footprint, but with few differences to the other three impact categories), the major part of differences among the groups are significant, although only in two situations (NEF-EFF and INT-EXT), the significance is given for both product- and surface-related indicators, which could be expected because of the kind of segregation. Further, the most efficient farms (EFF) show a behaviour that is closer to the extensive one, if the result is related to the surface, and to the intensives, if the result is related to the product. This suggests that these farms are best capable of combining a higher level of efficiency with a low level of environmental impact.

In the case of economic figures, the significance is only given for the groups EXT-EFF and NEF-EFF (Fig. 6). In the case of the pair EFF-INT, there is no significance in economic results, despite the fact that in the average the profit of the farm group EFF is higher than the group INT (Fig. 3). Nevertheless, the fact that in comparison with the other two groups (EXT and NEF) the results of the EFF group are better underlines that a better management also results in better economic figures. 

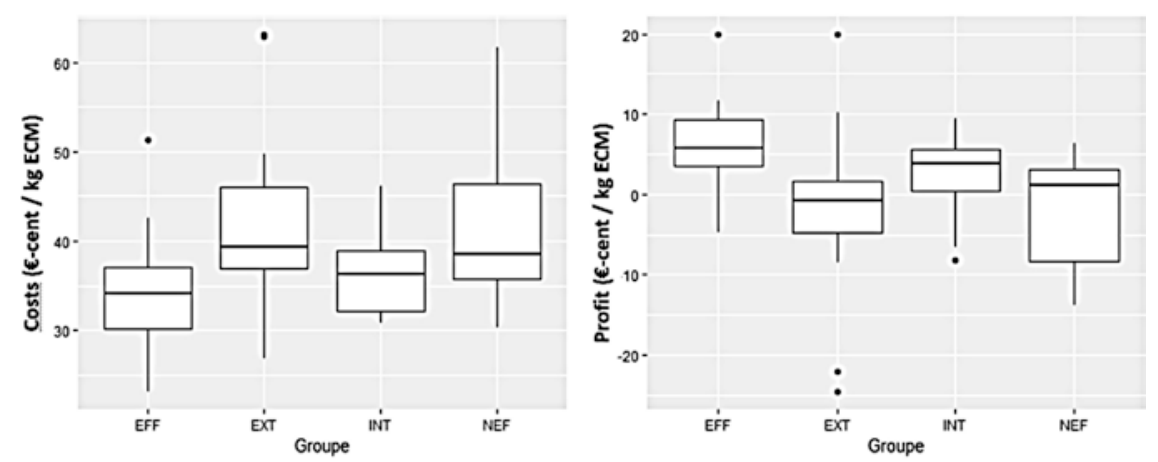

\begin{tabular}{|c|c|c|c|c|c|c|c|}
\hline Variable & $\begin{array}{c}\text { Significance } \\
\text { [ANOVA] }\end{array}$ & EXT-EFF & INT-EFF & NEF-EFF & INT-EXT & NEF-EXT & NEF-INT \\
\hline $\begin{array}{c}\text { Sum of costs (€) } \\
\text { Profit without } \\
\text { subventions (€) }\end{array}$ & 0,0023 & 0,0062 & ns & 0,0231 & ns & ns & ns \\
\hline
\end{tabular}

Fig. 6 Statistics of economic parameters for the farm groups ( $n s$ not significant)

\section{Main Conclusions}

- The use of product- and surface-related functional units allows a better understanding of differences in results among the farms.

- In particular, differences among intensive and extensive farms are mostly due to the farm structure, those among middle-intensive ones mostly to the efficiency in farm management.

- Although not always supported by statistics, there is evidence that efficient middle-intensive farms show better performance both environmentally and economically. Their environmental efficiency allows best economic performance.

- Based on this study, the conclusion that intensive farms always show better performance because of better product-related results cannot be confirmed.

- In times of liberalisation of milk quota, a smart feed management (especially of feed protein) seems to be a key lever for realising best performances both environmentally and economically.

\section{References}

1. IDÈLE. (2010). Guide pratique de l'alimentation du troupeau bovin laitier. IdèleEditions Quae.

2. GfE. (2001). Empfehlung zur Energie- und Nährstoffversorgung der Milchkühe und Aufzuchtrinder. DLG-Verlag.

3. DLG-Futterwerttabellen Wiederkäuer. (1997). 7. erweiterte und überarbeitete Auflage. DLG-Verlag. 
4. Lioy, R., Klöcker, D., Laugs, P., \& PetrY, J. (2019). Eiweißautarkie Luxemburger Milchviehbetriebe - Stand, Verbesserungs-potential, räumliche Variabilität. Internationale Grünlandtagung. http://www.grengland.lu/sites/default/files/files/brochure_iglt_2019_d_f_ v2_low.pdf. Accessed 15 Jan 2020

5. ECOINVENT. The live cycle inventory data, Version July 2009 https://www.ecoinvent.org/. Accessed 15 Jan 2020.

6. IPCC. (2006). Greenhouse gas inventory. Reference manual (vol. 4). https://www.ipcc-nggip. iges.or.jp/public/2006gl/vol4.html. Accessed 15 Jan 2020.

7. Leithold, G., Hülsbergen, K.-J., Michel, D., \& Schönmeier, H. (1997). Humusbilanzierung Methoden und Anwendung als Agrar-Umweltindikator. In Diepenbrock W., Kaltschmitt M., Nieberg H., Reinhardt G. (Hrsg.). Umweltverträgliche Pflanzenproduktion - Indikatoren, Bilanzierungsansätze und ihre Einbindung in Ökobilanzen. Zeller Verlag Osnabrück

8. Haenel, H.-D., Rösemann, C., Dämmgen, U., Poddey, E., Freibauer, A., Wulf, S., EurichMenden, B., Döhler, H., Schreiner, C., Bauer, B., \& Osterburg, B. (2014). Calculations of gaseous and particulate emissions from German agriculture 1990 - 2012: Report on methods and data (RMD) submission 2014. Johann Heinrich von Thünen-Institut, 348 p, Thünen Rep 17, 2014 https://www.thuenen.de/media/publikationen/thuenen-report/Thuenen-Report_17. pdf. Accessed 15 Jan 2020

9. Heijungs, R. (1992). Environmetal life cycle assessment of products - A guide of practice. Centre pf Environmental Centre (CML).

10. Kristensen, T., \& Kristensen, S. (2017). Proportion, type and utilization of grassland affects the environmental impact of dairy farming. http://labos.ulg.ac.be/dairyclim/de/literature/. Accessed 15 Jan 2020.

11. Lioy, R., Reding, R., Dusseldorf, T., \& Meier, A. (2012). CO2-emissions of 63 luxembourg livestock farms: A combined environmental and efficiency analysis approach. EMILI-Congress (Emission of Gas and Dust from Livestock) - Saint-Malo, France - June 10-13, 2012. https:// hal.archives-ouvertes.fr/hal-01190848/document. Accessed 15 Jan 2020.

12. Lioy, R., Dusseldorf, T., Meier, A., Reding, R., \& Turmes, S. (2014). Carbon footprint and energy consumption of Luxembourgish dairy farms. 11. In IFSA Symposium, Berlin 1-4 April 2014. http://ifsa.boku.ac.at/cms/fileadmin/Proceeding2014/WS_2_7_Lioy.pdf. Accessed 15 Jan 2020.

13. Lioy, R., Meier, A., Dusseldorf T., Reding, R., \& Thirifay, C. (2016). Sustainability assessment in Luxembourgish dairy production by CONVIS: A tool to improve both environmental and economical performance of dairy farms. In The 12th IFSA Symposium 2016, Harper Adams University, UK on 12-15 July 2016. http://ifsa.boku.ac.at/cms/fileadmin/Proceeding2014/ WS_2_7_Lioy.pdf. Accessed 15 Jan 2020.

14. https://www.r-project.org/. Accessed 15 Jan 2020.

15. Dagnelie, P. (1994). Théorie et methods statistiques (Vol. 2, 8th ed.). Gembloux.

16. Bracher, A. (Ed.). (2011). Möglichkeiten zur Reduktion von Ammoniakemissionen durch Förderungsmaßnahmen beim Rindvieh (Milchkuh). SHL, Agroscope.

17. Seó, H., Pinheiro, M. F., Ruviario, C., \& Léis, C. (2017, April). Avaliação do Ciclo de Vida na bovinocultura leiteira e as oportunidades ao Brasil. Engenharia Sanitaria e Ambiental, 22. https://doi.org/10.1590/s1413-41522016149096

18. Ross, S. A., Chagunda, M. G. G., Topp, C. F. E., \& Ennos, R. A. (2012). Effects of forage regime and cattle genotype on the global warming potential of dairy production systems. EMILI-Congress (Emission of Gas and Dust from Livestock) - Saint-Malo, France - June 10-13, 2012. https://hal.archives-ouvertes.fr/hal-01190848/document. Accessed 15 Jan 2020.

19. Grignard, A., Hennart, S., Laillet, C., Oenema, J., \& Stilmant, D. (2013). Bilan gaz à effet serre des ateliers laitiers des fermes pilotes Dayriman wallonnes selon la method GHG. In: Acts of the symposium "20 ans Rencontres Recherches Ruminants", Paris, France, December 4-5, 2013. 
20. Hermansen, J. E., \& Kristensen, T. (2011). Management options to reduce the carbon footprint of livestock products. Animal Frontiers, 1, 33-39.

21. Rotz, C. A., Montes, F., \& Chianese, D. S. (2010). The carbon footprint of dairy production systems through partial life cycle assessment. Journal of Dairy Science, 93, 1266-1282.

Open Access This chapter is licensed under the terms of the Creative Commons Attribution 4.0 International License (http://creativecommons.org/licenses/by/4.0/), which permits use, sharing, adaptation, distribution and reproduction in any medium or format, as long as you give appropriate credit to the original author(s) and the source, provide a link to the Creative Commons license and indicate if changes were made.

The images or other third party material in this chapter are included in the chapter's Creative Commons license, unless indicated otherwise in a credit line to the material. If material is not included in the chapter's Creative Commons license and your intended use is not permitted by statutory regulation or exceeds the permitted use, you will need to obtain permission directly from the copyright holder. 